Author's version. Jacquin, J. (2018). Argumentation in the Workplace. In B. Vine (Ed.), Handbook of Language in the Workplace (pp. 284-294). London: Routledge.

\title{
Argumentation in the Workplace
}

\author{
Jérôme Jacquin \\ University of Lausanne \\ jerome.jacquin@unil.ch
}

\section{INTRODUCTION AND DEFINITION}

Anyone wishing to examine Argumentation in the Workplace faces a variety of issues, the first being the very meaning of the word argumentation in English. Unlike in other Indo-European languages (e.g. French, German, Italian, Spanish, Dutch), argumentation is not a neutral term in English, but often has negative connotations. It is associated with "having an argument", which challenges the possibility of using the word in a scientific context and as a descriptive category. Another crucial difference is that the English word places a special emphasis on the process (i.e. the activity of arguing), rather than balancing, like in the aforementioned languages, argumentation as production and argumentation as product (i.e. the result of such activity). ${ }^{1}$ This complexity justifies beginning this chapter with a scientific definition of what argumentation is or can be:

Argumentation is a verbal and social activity of reason aimed at increasing (or decreasing) the acceptability of a controversial standpoint for the listener or reader, by putting forward a constellation of propositions intended to justify (or refute) the standpoint before a rational judge. (Van Eemeren, Grootendorst, and Snoeck Henkemans 1996, 5).

Such a definition requires additional explanation. First, argumentation arises in a situation of disagreement (see also Doury 2012; Plantin 2005), which can be in praesentia (i.e. the opposing positions are defended by two different interacting participants) or in absentia (i.e. at least one 
speaker argues against a position that no other participant in the interaction defends). Second, argumentation is not taken to be the verbal activity of persuading people in order to solve the disagreement. As has been examined by Angenot (2008) and Plantin (2012), persuasion is a bad candidate for a general definition, even if, in some cases, argumentation is - actually and systematically - oriented to persuading the addressee (e.g. in the legal context). Instead of persuasion, the definition given above highlights the importance of the two complementary goals that Angenot identifies as being the core features of argumentation: people argue to justify a standpoint and to position it in the disagreement. Third, as a "verbal activity" that requires the speaker to produce a "constellation of propositions", argumentation can be analyzed from a linguistic and descriptive point of view, by examining the way justification and positioning are grounded in language, discourse, and interaction (Jacquin and Micheli 2012).

Argumentation Theory is a relatively young scientific field. However, as argumentation is now considered as one of the verbal underpinnings of reasoning and decision-making in ordinary and institutional settings, it has become a popular topic in human and social sciences. In much the same way as classical Rhetoric, argumentation is viewed as the skeleton of democracy, where citizens are expected not only to hold an opinion, but also to support it with arguments (Danblon 2004; Van Eemeren 2015, chap. 45). The same can be said about private companies and public institutions, where decisions are increasingly expected to be made dialectically (i.e. by taking others' points of view into account).

The aim of this chapter is to provide a general overview of argumentation as being part of the analysis of language in the workplace. This includes surveying studies which examine talk at 
work, i.e. studies that explicitly and reflectively address, from a language-oriented perspective, relevant topics in workplace studies, such as leadership, decision-making, workflows, and professional and employable identities. Such a scope goes beyond what happens in private companies; it also concerns the work done by the representatives of organizations and institutions, both internally and externally, i.e. in the public sphere (e.g. constitutions and laws, parliamentary debates, awareness and election campaigns, presidential addresses, press conferences). In other words, argumentation at work is understood here as argumentation provided in a professional context, i.e. where at least one arguer assumes a professional identity (e.g. lawyer, manager, sales assistant, president of the United States) in a professional setting (e.g. court, doctor's office, parliament, press conference).

Section 2 provides historical perspectives in Argumentation Theory, while Section 3 introduces the main research methods that are relevant for a language-oriented study of argumentation at work as well as examples of current contributions. Section 4 discusses the main crucial issues and topics related to argumentation at work. The chapter concludes with a discussion of future directions of research (Section 5).

\section{HISTORICAL PERSPECTIVES}

As Van Eemeren et al. pointed out, « a great many of the theoretical concepts as well as a large part of the terminology used in present-day approaches to argumentation are adopted from or inspired by the classical disciplines of dialectic, logic, and rhetoric » $(2014,52)$. Aristotle $(384-322$ BC) has certainly been the most influential thinker in the field. Aristotle's Logic introduces the universal, logical patterns that the speaker can use to establish the truth of a statement; his Dialectic gathers the techniques for reasoning and decision-making through critical discussion; while his Rhetoric is the art of persuading an audience in context. Logic, 
dialectic, and rhetoric were part of the then-emerging democracy and public organization of citizenship in ancient Greece. During Late Antiquity (Cicero and Quintilian) and Early Middle Ages (St. Augustine and Boethius), logic became progressively part of dialectic. As a consequence, the rhetorical and (logical-)dialectical perspectives were clearly separated and even opposed during the sixteenth and seventeenth centuries.

In 1958, two books made crucial contributions to the emergence and consolidation of Argumentation Theory as an independent field and as a method for going beyond formal logic, which emerged in the nineteenth century, and beyond the classical opposition between dialectic and rhetoric, by tackling argumentation as a practical and situated phenomenon. These books are The Uses of Argument by Toulmin (1958) and La Nouvelle Rhétorique, traité de l'argumentation [The New Rhetoric: A treatise on argumentation] by Perelman and OlbrechtsTyteca (1958, translated into English in 1969).

Toulmin's book is well-known for its description of the argumentation layout, which schematizes the practical procedure and its constitutive steps that allow the arguer to draw a conclusion or "claim" (e.g. person P must be helped) from a fact or "data" (e.g. person P is threatened). This procedure highlights the importance of the "warrant", which is the general rule or value that is applied to the case and which often remains implicit (e.g. one must provide assistance to people in danger). In some cases, the warrant can be legally consolidated by a "backing" (e.g. as stated in law L). By using a "modal qualifier" the arguer can also display the degree of certainty of the claim (e.g. maybe), while the "rebuttal" is a way to provide for an exception to the procedure (e.g. unless person P is threatening someone else). Toulmin's layout not only systematizes notions such as warrant, claim or rebuttal, but it also provides a general framework for the analysis of natural argumentation and practical reasoning, as it is used in a wide diversity of contexts. Contrasting with formal logic, this is consistent with what Toulmin says about evaluation criteria: while the layout is universal, the norms that are used to evaluate 
argumentation are contextual and historical and "[they] depend on the nature of the problem at issue" (Van Eemeren et al. 2014, 211). The context-dependency of such "non-idealized practical logic" (ibid., 212) calls for empiricism, as a way to tackle the diversity of the professional and non-professional - spheres, situations, and types of dialogue. Because of the different aspects of argumentation it covers, Toulmin's account has impacted various subfields in Argumentation Theory, and some language-oriented approaches to argumentation have reexamined Toulmin's argumentative layout from a linguistic perspective (see below, Section 3).

The wish to move beyond formal logic we find in Toulmin's work can also be taken to underlie Perelman and Olbrechts-Tyteca's New Rhetoric. Drawing from Aristotle's Dialectic and Rhetoric, the authors examine argumentation as a way of justifying practical decisions and actions, rather than as a means to support abstract and decontextualized reasoning. Such context-dependency highlights the crucial importance of the audience, to which the arguer must adapt in order to increase the persuasiveness of argumentation or the intensity of adherence. This does not mean that the audience is independent from the argumentative performance: in order to be persuasive, the speaker needs both to strategically construct the audience and to adapt to it accordingly (e.g. categorizing recipients as patriots in a declaration of war, or addressing judges as parents in a trial on child murder). Argumentation is then intrinsically dialectical - even when the audience remains silent and no explicit interaction emerges - as the arguer must anticipate potential objections or agreements from the strategically addressed audience. Perelman and Olbrechts-Tyteca make a distinction between argumentation based on the structure of reality (facts, truths, presumptions), which target a universal audience, and argumentation based on the preferable, which target a particular audience by mobilizing shared values. As in Toulmin's model, context-dependency calls for descriptive empiricism, and classical rhetoric is thus extended - beyond the political and legal spheres - to the analysis of 
ordinary and professional argumentation, be it embedded in written texts or in oral interaction. ${ }^{2}$

\section{MAIN RESEARCH METHODS AND CURRENT CONTRIBUTIONS}

I now introduce four language- and corpus-oriented approaches to argumentation that emerged from classical and post-classical studies and that are currently used in the analysis of argumentative practices at work. Three are grounded in linguistics and take a descriptive stance $^{3}$, while the last is associated with communication studies and is critical and normative. Each approach is exemplified by a selection of monographs, edited books, and doctoral dissertations - mostly in French and English - that illustrate current contributions and research on various professional domains or spheres where argumentation plays a crucial role (see also Van Eemeren and Garssen 2012).

The first approach to be mentioned is the discursive model "Argumentation dans le discours" ([argumentation in discourse], Amossy 2009; Amossy 2010). This model draws on both French Discourse Analysis and Perelman's New Rhetoric in order to analyze the "argumentative orientation" of discourses (Amossy 2005). Particular attention is paid to genres, stereotypes, identities and emotions in a large variety of domains, whether literary or non-literary (on media talk and political communication, see Amossy and Burger 2011; Bonhomme and Rossari 2013; on diplomatic correspondence, see Cohen-Wiesenfeld 2007). In this framework, argumentation is defined as a verbal method for influencing people by modifying their beliefs and representations. The model stresses the importance of dialogism (i.e. reported speech, polyphony, and intertextuality) in order to capture the coexistent argumentative voices and the state of controversies that surround the arguer. 
The second approach is the Modèle dialogal de l'argumentation ([dialogical model of argumentation], also known as the Question->AnswerS Model; Plantin 2005; Plantin 2012). It examines argumentation as it is linguistically and sequentially implemented in written or oral talk-in-interaction. Argumentation is not defined in terms of its potential, external effect or orientation (e.g. persuading or influencing someone), but in terms of its internal dynamics (i.e. justification and positioning; Jacquin and Micheli 2012) and as a verbal means, among others, of managing disagreements and conflicts. In this sense, argumentation emerges when a difference of opinion not only arises, but "crystallizes" (Traverso 2005) through the linguistic, discursive, and interactional construction and consolidation of opposing positions with respect to a controversial question (Doury 1997; Jacquin 2014). The model has been applied to various political contexts. such as parliamentary (Micheli 2010), televised (Doury 1997), and public debates (Jacquin 2014). The analysis of the way politicians justify standpoints and position themselves in the disagreement gives insights into the role of argumentation in the vitality of the public sphere, in the emergence and organization of democracy, and in the discussion of political topics, values, and ideologies. Multimodality has recently been integrated into the model, with a focus on the role of gestures and shifts in gaze direction in segmenting argumentative moves (Jacquin, n.d.) and in making reference to the contested position (Jacquin 2015).

The third approach is the Argumentum Model of Topics (Rigotti and Greco Morasso 2009; Rigotti and Greco Morasso 2010). This model combines classical Rhetoric and modern approaches to argumentation schemes (e.g. Perelman and Olbrechts-Tyteca 1958; Walton, Reed, and Macagno 2008; see also below, Section 4) in order to model and elicit the complete picture of the "inferential configuration" that connects the argument with the standpoint. The model also integrates a semantic analysis of keywords and modals in order to gain access to the 
linguistic underpinnings - or indicators - of argumentative structures (Rigotti and Rocci 2005). The model has been used to analyze argumentation in various domains, with a focus on financial communication about takeover bids (Palmieri 2014) and dispute mediations in companies and institutions (Greco Morasso 2011). Recent studies investigate argumentation in news production workflows, examining how decisions regarding editorial choices are expressed and justified in the newsroom (Zampa 2015; Andone and Rocci 2016).

Finally, the Pragma-Dialectical Model of Amsterdam is a well-known and influential approach to argumentation, which it defines as the way in which arguers aim to "resolve [a] difference of opinion by achieving agreement on the acceptability or unacceptability of the standpoint(s) involved through the conduct of a regulated exchange of views" (Van Eemeren and Grootendorst 2004, 58). The model ascribes equal importance to the analysis and the evaluation of argumentation. In order to fulfill this goal, "rules for a critical discussion" have been established and applied as an ideal framework to analyze actual communicative practices. ${ }^{4}$ Particular attention is paid to what the model calls "reconstruction", which is an analytical step where empirical argumentation is simplified and summarized by the analyst as a method for drawing a general picture of the speech event. The model has recently incorporated some linguistic observations (on "argumentative indicators", see Van Eemeren, Houtlosser, and Snoeck Henkemans 2007) as well as a rhetorical component (on "strategic maneuvering", see Van Eemeren 2010), but the normative and communication-oriented stance of the approach remains central and the Pragma-Dialectical Model should be distinguished - from this perspective - from empirical, descriptive language-oriented approaches. In the domain of political argumentation, much has been done on strategic maneuvering in various genres of political deliberation (Lewiński and Mohammed 2015), such as parliamentary debates (Tonnard 2011; Mohammed 2009) and political interviews (Andone 2013). The model has also 
been applied to law and available studies in legal argumentation focus on the way guilt is discursively established, punishment justified, testimony contested, decisions made, and convictions handed down in various legal cultures (Feteris 2005; Feteris 1999; Dahlman and Feteris 2013). In the health sector (Rubinelli and Snoeck Henkemans 2012), recent studies have focused on argumentation in health brochures (Van Poppel 2013) and medical consultations (Pilgram 2015; Labrie 2013).

\section{CRITICAL ISSUES AND TOPICS}

From said the overview provided in the previous section, it is now possible to summarize five critical issues and topics that are of particular interest for a language-oriented analysis of argumentation at work. While the first topic, (i) from disagreeing to decision-making, tackles the whole process in which argumentation plays a crucial role, the others are adapted from Arisotle's Rhetoric, which, as mentioned above, has been crucially influential for current methods and contributions about argumentation in professional contexts. (ii) Genre provides the general outline for the participants to tackle the disagreement in an argumentative way. The other three are connected to Aristotle's rhetorical proofs: (iii) argumentation schemes and structures (logos), (iv) authority and credibility (ethos), (v) emotions (pathos).

\section{(i) From disagreeing to decision-making}

Since disagreement is the starting point of argumentation, it is of particular interest to examine how it is expressed, polarized, and managed in context. The first task is to identify the relevant roles of the argumentative situation: "the proponent engages in a discourse of proposition; the opponent, in a counterdiscourse, or discourse of opposition; the third party takes responsibility for the topic of the argument" (Plantin 2002, 363). Such roles can be taken by one, two, three or more speakers, varying from inner dialogue to complex, multi-party argumentative situations 
(Doury 2012; Plantin 1996). The analyst may wish to examine the presence or absence of politeness, mitigation, and mediation strategies in the expression and management of disagreement and to evaluate to what extent it relates to the professional status of the participants (i.e. employer, employee, colleague). Examples of other relevant questions are: Does the disagreement emerge during a specific phase of the speech event (e.g. introduction of a new topic, brainstorming, decision-making)? Does the disagreement concern only the writers/speakers or do the participants refer, through reported speech or polyphonic markers, to other points of view or voices that are expressed by absent persons or non-represented institutions (e.g. Fløttum, Dahl, and Kinn 2006, chap. 6)?

At the other end of the chain, decisions can be viewed as results to be achieved by professional workflows, whether they are in companies, institutions, or the public sphere (e.g. democratic elections or votes). Decision-making is then crucial for the study of argumentation in the workplace. Depending on the genre (see below), argumentation can be oriented to disagreement resolution, be it through persuasion/alignment (the decision is made as soon as people are convinced) or simply justification (the decision has already been made but it has to be justified in order to be better accepted). The analyst should pay particular attention not only to the arguments that are used and to the order in which they are introduced, but also to the linguistic resources that have been selected to express the decision (e.g. Gunnarsson 2006; see Rieke, Sillars, and Peterson 2013 for a communication-oriented perspective).

\section{(ii) Genre}

Genres, such as parliamentary debates, press conferences, constitutional texts, judicial reviews, advertisements, or management meetings, are crucial since they provide the general framework to tackle the complexity of argumentation structures as they emerge in empirical data, whether they are written texts, oral speeches, or polylogues (on "genre", see Bhatia 1993; Swales 1990). Analyzing a decontextualized argumentative sequence of three sentences is one thing, but 
drawing the entire argumentative picture of a speech event is another. When the different positions in the disagreement are defended by more than one person, coalitions of people - or "parties" - defending the same position can occur, whilst splitting and disagreeing on subtopics (Jacquin 2014; Lewiński and Aakhus 2014). From a language-oriented perspective, it is thus of particular relevance to consider the sequentiality of both spoken and written argumentation. This allows one to examine the "interpretation" of the argumentative moves from the participants" point of view (i.e. "emic" perspective, following Pike 1954), and not only as a purely a posteriori "reconstruction" by the analyst (on the difference between argumentation interpretation and argumentation reconstruction in Pragma-Dialectics, see Van Rees 2001). As they provide the canvas for the argumentative structure, genres are also crucial when considering the formal and functional complexity of multimodal argumentation, i.e. argumentation based on a combination of various semiotic resources, such as language, gestures, gaze, images, documents, or movies (e.g. Birdsell and Groarke 1996; Tseronis and Forceville, n.d.; Van Belle et al. 2013).

Genre also relates to the degree to which argumentation is oriented towards persuasion (e.g. Amossy 2009; Van Eemeren 2010; Walton 1998). For example, in televised or parliamentary debates, although the debaters do not try to persuade each other, the viewer may be targeted, especially when a decision is pending (e.g. during referendums or election campaigns). However, when the decision has already been made, argumentation provides only reasons justifying a standpoint against another, most often without any orientation to persuasion.

Finally, and as already noted by Toulmin (see Section 2), genres are of crucial importance when examining the norms, values, and evaluation criteria that are in use to assess in context the quality or acceptability of argumentation provided. In others words, norms are indexical, since they pertain to specific genres (Goodwin 2005; Plantin 2005). For instance, "The scientific inquiry $[\ldots]$ requires that proof proceed only from premises that either are axiomatic or can be 
established by methods of inference accepted by standards in a particular branch of scientific knowledge" (Walton 1998, 32).

\section{(iii) Argumentation schemes and structures (logos)}

Argumentation schemes consist of the different "forms of argument (structures of inference)" (Walton, Reed, and Macagno 2008, 1) or reasoning strategies that the arguer can use to draw a conclusion form an argument. For instance, the "argument from positive consequences" is based on "causal reasoning": "A should be brought about" because "if A is brought about, then good consequences will occur" (ibid., 101). This "practical reasoning" differs from other schemes, such as "argumentation from values" or "argument from rules". It is therefore relevant to identify the schemes that are used and the way they contribute to the disagreement. For instance, two managers can disagree on whether or not to fire employee E by selecting and putting forward different kinds of argumentation schemes. While the first manager claims that firing E would lower the operating costs (argument from positive consequence), the second argues that E should not be fired since that would contradict the company's ethics, which state that people are more important than benefits (argument from values). Argumentation schemes thus provide a window on various modes of reasoning as well as on the hierarchy of values and ideologies that is at stake in a professional context or culture. Argumentation schemes also help the analyst not only to segment the talk into argumentative moves, but also to examine argumentation structures, i.e. how arguments and conclusions are coordinated in such a way as to strengthen the defended position in the disagreement.

\section{(iv) Authority and credibility (ethos)}

Credibility and authority are crucial dimensions of workplace studies. Authority, on one hand, relates to the professional status of the speaker (e.g. employer VS employee; expert VS lay) or 
the person, group or organization upon whom the arguer bases their argumentation (i.e. in the case of arguments from a "position to know", such as appeal to expert opinion or testimony; Walton, Reed, and Macagno 2008; Zemplén and Kutrovátz 2011). On the other hand, credibility is derived from the rhetorical performance in context (on the distinction between authority and credibility in argumentation, see Charaudeau 2009). Credibility relates to ethos, being the image of the self that the arguer displays, through talk-in-interaction, in order to strengthen their argumentation. Ethos can be challenged by ad hominem arguments, which are attacks on the arguer's credibility (e.g. by highlighting a logical inconsistency between two incompatible arguments put forward by the arguer). Leadership is an example of a relevant in-between category: depending on the situation (e.g. management meeting VS peer collaboration), the authority of the leader can be based on a professional status, but the credibility of the leader always needs to be established in context, through their discursive and interactional ability to justify their opinions, position themselves in the disagreement and, sometimes, argumentatively mediate emerging conflicts.

\section{(v) Emotions (pathos)}

Beside ethos, pathos is another rhetorical means by which the arguer can strengthen the argumentation. Classic examples of pathos are appeals to shame, fear or pity. In those cases, emotion functions as a support for the ongoing argumentation. Emotions can also become objects of argumentation. This is the case when the relevance of expressing a specific emotion in context - such as feeling pity for victims - is disputed (e.g. Micheli 2010 on French parliamentary debates on the abolition of death penalty; see Plantin 2004 for a general introduction to the topic). Such rationality of emotions is important in the workplace: how are emotions verbally expressed by the participants and how are they articulated with the defended 
standpoint? What is the role of such rationalized emotions in the structure of the text, the organization of the interaction, or, more generally, the workflow?

\section{FUTURE DIRECTIONS}

Coming to the end of this chapter, it should be noted that even if various language-oriented approaches to argumentation have been applied to different professional settings, no study in Argumentation Theory precisely defines workplace discourses and interactions or grounds its observations in workplaces studies. In other words, no matter the setting that is analyzed, workrelated issues are not addressed as such and it is very unusual to read studies on argumentation that are based on an explicit method or theory for the analysis of workplace language and interaction (e.g. Drew and Heritage 1992; Filliettaz and Bronckart 2005; Holmes, Marra, and Vine 2011). In addition, while many workplace studies in Argumentation Theory focus on written or spoken monologues, few exist on argumentative talk-in-interaction. Developing the theoretical, methodological, and analytical dimensions of the study of Argumentation in the Workplace therefore still remains a challenge. And there is much to be done on the relationship between argumentation and gender, power, or ideology at work.

\section{FURTHER READING}

- Van Eemeren, Frans H, Bart Garssen, Erik C. W. Krabbe, Francisca Snoeck Henkemans, Bart Verheij, and Jean H.M. Wagemans. 2014. Handbook of Argumentation Theory. Dordrecht: Springer.

This handbook provides an extensive overview of the historical roots, theoretical backgrounds and current contributions in Argumentation Theory.

- Doury, Marianne, and Sophie Moirand, eds. 2004. L'argumentation Aujourd'hui: Positions Théoriques En Confrontation. Paris: Presses Sorbonne Nouvelle.

This book brings together different perspectives on what argumentation is and how it can be analyzed from a language-oriented point of view. 
- Van Eemeren, Frans H, and Bart Garssen, eds. 2012. Exploring Argumentative Contexts.

Amsterdam:

John

Benjamins.

This book gathers essays examining argumentation in a wide variety of professional contexts, including politics, law, health and the media.

\section{ACKNOWLEDGEMENTS}

The author has been supported in 2014 and 2015 by the Swiss National Science Foundation [P2LAP1_155110]. He is most grateful to Bernadette Vine, Steve Oswald, and two anonymous reviewers for their helpful comments on a previous version of this paper and to Keely Kidner for correcting his English.

\section{REFERENCES}

Amossy, Ruth. 2005. "The Argumentative Dimension of Discourse." In Argumentation in Practice, edited by Frans H. Van Eemeren and Peter Houtlosser, 87-98. Amsterdam: John Benjamins.

- 2009. "Argumentation in Discourse: A Socio-Discursive Approach to Arguments." Informal Logic 29 (3): 252-67.

. 2010. L'argumentation Dans Le Discours. 3rd ed. Paris: Armand Colin.

Amossy, Ruth, and Marcel Burger, eds. 2011. Polémiques Médiatiques et Journalistiques. Le Discours Polémique En Question(s) / Semen 31.

Andone, Corina. 2013. Argumentation in Political Interviews: Analyzing and Evaluating Responses to Accusations of Inconsistency. Amsterdam: John Benjamins.

Andone, Corina, and Andrea Rocci, eds. 2016. Argumentation in Journalism: Professional Practices and the Public Sphere / Journal of Argumentation in Context 5(1). Amsterdam: John Benjamins.

Angenot, Marc. 2008. Dialogues de Sourds : Traité de Rhétorique Antilogique. Paris: Mille et une nuits.

Anscombre, Jean-Claude, and Oswald Ducrot. 1983. L'argumentation Dans La Langue.

Bruxelles: Mardaga.

Bhatia, Vijay K. 1993. Analysing Genre: Language Use in Professional Settings. London:

Longman.

Birdsell, David S, and Leo Groarke. 1996. "Toward a Theory of Visual Argument." Argumentation and Advocacy 33: 1-10.

Bonhomme, Marc, and Corinne Rossari. 2013. L'argumentation Dans Le Discours Politique / Argumentation \& Analyse Du Discours 10. https://aad.revues.org/1424.

Charaudeau, Patrick. 2009. "L'argumentation Dans Une Problématique D’influence."

Argumentation et Analyse Du Discours, no. 1. http://aad.revues.org/193.

Cohen-Wiesenfeld, Sivan. 2007. "Le Discours Diplomatique - Analyse de La

Correspondance Diplomatique Entre La France et l'Allemagne Entre 1871 et 1914.” Doctoral dissertation, Tel Aviv: Tel Aviv University.

Dahlman, Christian, and Eveline T. Feteris, eds. 2013. Legal Argumentation Theory: Cross- 
Disciplinary Perspectives. Dordrecht: Springer.

Danblon, Emmanuelle. 2004. Argumenter En Démocratie. Bruxelles: Labor.

Doury, Marianne. 1997. Le Débat Immobile. L'argumentation Dans Le Débat Médiatique Sur Les Parasciences. Paris: Kimé.

— 2012. "Preaching to the Converted. Why Argue When Everyone Agrees?"

Argumentation 26 (1): 99-114.

Doury, Marianne, and Sophie Moirand, eds. 2004. L'argumentation Aujourd'hui : Positions

Théoriques En Confrontation. Paris: Presses Sorbonne Nouvelle.

Drew, Paul, and John Heritage, eds. 1992. Talk at Work: Interaction in Institutional Settings.

Cambridge: Cambridge University Press.

Fairclough, Isabela, and Norman Fairclough. 2012. Political Discourse Analysis. London;

New York: Routledge.

Feteris, Eveline T. 1999. Fundamentals of Legal Argumentation. A Survey of Theories on the Justification of Judicial Decisions. Dordrecht: Springer.

—., ed. 2005. Schemes and Structures of Legal Argumentation / Argumentation 19(4).

Dordrecht: Springer.

Filliettaz, Laurent, and Jean-Paul Bronckart, eds. 2005. L'analyse Des Actions et Des

Discours En Situation de Travail. Louvain: Peeters.

Fløttum, Kjersti, Trine Dahl, and Torodd Kinn. 2006. Academic Voices: Across Languages

and Disciplines. Amsterdam: John Benjamins.

Goodwin, Jean. 2005. "Designing Premises." In Argumentation in Practice, edited by Frans

H. Van Eemeren and Peter Houtlosser, 99-114. Amsterdam: John Benjamins.

Greco Morasso, Sara. 2011. Argumentation in Dispute Mediation: A Reasonable Way to

Handle Conflict. Amsterdam: John Benjamins.

Grize, Jean-Blaise. 1982. De La Logique Naturelle à L'argumentation. Genève: Droz.

Gunnarsson, Magnus. 2006. "Group Decision-Making - Language and Interaction.” Doctoral dissertation, Göteborg: Göteborg University.

Hamblin, Charles L. 1970. Fallacies. London: Methuen.

Holmes, Janet, Meredith Marra, and Bernadette Vine. 2011. Leadership, Discourse and

Ethnicity. Oxford: Oxford University Press.

Jacquin, Jérôme. 2014. Débattre. L'argumentation et L'identité Au Coeur D'une Pratique

Verbale. Bruxelles: De Boeck.

2015. "Multimodal Counter-Argumentation in the Workplace: The Contribution of

Gesture and Gaze to the Expression of Disagreement." In GESPIN 4 Proceedings, 155-60.

Nantes.

. n.d. "Embodied Argumentation in Public Debates. The Role of Gestures in the

Segmentation of Argumentative Moves." In Multimodal Argumentation and Rhetoric in

Media Genres, edited by Assimakis Tseronis and Charles Forceville. Amsterdam: John

Benjamins.

Jacquin, Jérôme, and Raphaël Micheli. 2012. "Entre Texte et Interaction : Propositions

Méthodologiques Pour Une Approche Discursive de L'argumentation En Sciences Du

Langage." In Actes Du CMLF 2012 - 3ème Congrès Mondial de Linguistique Française, edited by Franck Neveu, Valelia Muni Toke, Peter Blumenthal, Thomas Klingler, Pierluigi Ligas, Sophie Prévost, and Sandra Teston-Bonnard, 599-611. Lyon: EDP Sciences.

Labrie, Nanon. 2013. "For the Sake of Argument: Considering the Role, Characteristics, and Effects of Argumentation in General Practice Consultation." Doctoral dissertation, Università della Svizzera italiana: Lugano.

Lewiński, Marcin, and Mark Aakhus. 2014. "Argumentative Polylogues in a Dialectical

Framework: A Methodological Inquiry.” Argumentation 28 (2): 161-85.

Lewiński, Marcin, and Dima Mohammed, eds. 2015. Argumentation in Political Deliberation. 
Amsterdam: John Benjamins.

Micheli, Raphaël. 2010. L'émotion Argumentée. L'abolition de La Peine de Mort Dans Le Débat Parlementaire Français. Paris: Le Cerf.

Mohammed, Dima. 2009. "The Honourable Gentleman Should Make up His Mind. Strategic Manoeuvring with Accusations of Inconsistency in Prime Minister's Question Time."

Doctoral dissertation, Amsterdam: University of Amsterdam.

Palmieri, Rudi. 2014. Corporate Argumentation in Takeover Bids. Amsterdam: John Benjamins.

Perelman, Chaïm, and Lucie Olbrechts-Tyteca. 1958. La Nouvelle Rhétorique. Traité de l'Argumentation. 2 vols. Paris: PUF.

Pike, Kenneth L. 1954. Language in Relation to a Unified Theory of the Structure of Human Behavior / Part 1. Glendale: Summer Institute of linguistics.

Pilgram, Roosmaryn. 2015. "A Doctor's Argument by Authority: An Analytical and Empirical Study of Strategic Manoeuvring in Medical Consultation." Doctoral dissertation, Amsterdam: University of Amsterdam.

Plantin, Christian. 1996. "Le Trilogue Argumentatif. Présentation de Modèle, Analyse de Cas." Langue Française, no. 112: 9-30.

. 2002. "Argumentation Studies and Discourse Analysis: The French Situation and Global Perspectives.” Discourse Studies 4 (3): 343-68.

- 2004. "On the Inseparability of Emotion and Reason in Argumentation." In Emotions in Dialogic Interactions, edited by Weigand, E., 265-75. Paris: Presses Sorbonne Nouvelle. 2005. L'argumentation: Histoire, Théories et Perspectives. Paris: PUF. 2012. "Persuasion or Alignment?" Argumentation 26 (1): 83-97.

Reisigl, Martin, and Ruth Wodak. 2001. Discourse and Discrimination: Rhetorics of Racism and Antisemitism. London; New York: Routledge.

Rieke, Richard D., Malcolm O. Sillars, and Tarla Rai Peterson. 2013. Argumentation and Critical Decision Making. 8th ed. Boston: Pearson Education.

Rigotti, Eddo, and Sara Greco Morasso. 2009. "Argumentation as an Object of Interest and as a Social and Cultural Resource." In Argumentation and Education, edited by Nathalie Muller Mirza and Anne-Nelly Perret-Clermont, 9-66. Dordrecht: Springer.

- 2010. "Comparing the Argumentum Model of Topics to Other Contemporary

Approaches to Argument Schemes: The Procedural and Material Components."

Argumentation 24 (4): 489-512.

Rigotti, Eddo, and Andrea Rocci. 2005. "From Argument Analysis to Cultural Keywords (and Back Again)." In Argumentation in Practice, edited by Frans H Van Eemeren and Peter Houtlosser, 125-42. Amsterdam: John Benjamins.

Rubinelli, Sara, and Francisca Snoeck Henkemans, eds. 2012. Argumentation and Health. Amsterdam: John Benjamins.

Swales, John. 1990. Genre Analysis. Cambridge: Cambridge University Press.

Tonnard, Y. M. 2011. "Getting an Issue on the Table. A Pragma-Dialectical Study of Presentational Choices in Confrontational Strategic Maneuvering in Dutch Parliamentary Debate." Doctoral dissertation, Amsterdam: University of Amsterdam.

Toulmin, Stephen E. 1958. The Uses of Argument. Cambridge: Cambridge University Press. Traverso, Véronique. 2005. "Cristallisation Des Désaccords et Mise En Place de Négociations Dans L'interaction : Des Variations Situationnelles." In La Négociation Au Travail, edited by Michèle Grosjean and Lorenza Mondada, 43-69. Lyon: PUL.

Tseronis, Assimakis, and Charles Forceville, eds. n.d. Multimodal Argumentation and Rhetoric in Media Genres. Amsterdam: John Benjamins.

Van Belle, Hilde, Paul Gillaerts, Baldwin Van Gorp, Dorien Van De Mieroop, and Kris Rutten, eds. 2013. Verbal and Visual Rhetoric in a Media World. Amsterdam: Leiden 
University Press.

Van Eemeren, Frans H. 2010. Strategic Maneuvering in Argumentative Discourse: Extending the Pragma-Dialectical Theory of Argumentation. Amsterdam: John Benjamins.

Van Eemeren, Frans H. 2015. Reasonableness and Effectiveness in Argumentative Discourse. Dordrecht: Springer.

Van Eemeren, Frans H, and Bart Garssen, eds. 2012. Exploring Argumentative Contexts. Amsterdam: John Benjamins.

Van Eemeren, Frans H, Bart Garssen, Erik C. W. Krabbe, Francisca Snoeck Henkemans, Bart Verheij, and Jean H.M. Wagemans. 2014. Handbook of Argumentation Theory. Dordrecht: Springer.

Van Eemeren, Frans H, and Robert Grootendorst. 2004. A Systematic Theory of Argumentation: The Pragma-Dialectical Approach. Cambridge: Cambridge University Press. Van Eemeren, Frans H, Rob Grootendorst, and Francisca Snoeck Henkemans, eds. 1996.

Fundamentals of Argumentation Theory: A Handbook of Historical Backgrounds and Contemporary Developments. New York: Routledge.

Van Eemeren, Frans H, P Houtlosser, and A F Snoeck Henkemans, eds. 2007. Argumentative Indicators in Discourse: A Pragma-Dialectical Study. Dordrecht: Springer.

Van Poppel, Lotte. 2013. "Getting the Vaccine Now Will Protect You in the Future! A Pragma-Dialectical Analysis of Strategic Maneuvering with Pragmatic Argumentation in Health Brochures." Doctoral dissertation, Amsterdam: University of Amsterdam.

Van Rees, M A. 2001. "Argument Interpretation and Reconstruction." In Crucial Concepts in Argumentation Theory, edited by Frans H. van Eemeren, 165-99. Amsterdam: Sic Sat.

Walton, Douglas. 1998. The New Dialectic: Conversational Contexts of Argument. Toronto: University of Toronto Press.

Walton, Douglas, Christopher Reed, and Fabrizio Macagno. 2008. Argumentation Schemes. Cambridge: Cambridge University Press.

Zampa, Marta. 2015. "News Values as Endoxa of Newsmaking. An Investigation of Argumentative Practices in the Newsroom." Doctoral dissertation, Lugano: Università della Svizzera italiana.

Zemplén, Gabor Á., and Gabor Kutrovátz, eds. 2011. Rethinking Arguments from Experts / Argumentation 25(3). Dordrecht: Springer.

\footnotetext{
${ }^{1}$ For a more in-depth overview of the meaning of the word argumentation in different languages, see Plantin (2002, 344-346) and Van Eemeren et al. (2014, 3-5).

${ }^{2}$ The formal-dialectical approach to argumentation introduced by Hamblin (1970) is another post-classical study that has been important for the development of Argumentation Theory. Hamblin's "formal dialectic" is logical since it aims to define and systematize different "dialectical systems", which are regulated speech-exchange patterns with specific rules and properties. Such systems are introduced as a way of tackling the difficult issue of analyzing fallacies. Because it is formal and logical, Hamblin's model has been less crucially influential for the development of the language-oriented approaches to argumentation.

${ }^{3}$ As noted by Van Eemeren et al. (2014), the linguistic approaches to argumentation are grounded in studies by French scholars (see also Doury and Moirand 2004); first of all Anscombre and Ducrot's semantic approach Argumentation dans la langue [argumentation in language] (1983) and Grize's semio-cognitive approach Logique naturelle [natural logic] (1982). Both approaches have been very influential in the development of the languageoriented models mentioned in the present section. However, they are not outlined here in more depth, since they do not aim to analyze argumentation in context and examine it as a specific verbal practice: while Anscombre and Ducrot's radical perspective on argumentation consists of examining the argumentative orientation that is embedded in all the words of a given language, Grize associates argumentation with the general principle of influence (i.e. the modification of beliefs and representations through communication).

${ }^{4}$ These rules have been incorporated in Critical Discourse Analysis by Reisigl and Wodak (2001) and Fairclough and Fairclough (2012).
} 